\title{
MENUMBUHKAN KESADARAN MASYARAKAT MELALUI SOSIALISASI KEBIASAAN HIDUP BARU DI MASA PANDEMI COVID-19
}

\author{
${ }^{1}$ Meilanny Budiarti Santoso, ${ }^{2}$ Moch. Zainudiin, ${ }^{3}$ Dessy Hasanah Siti Asiah \\ 1'meilanny.budiarti@unpad.ac.id; ${ }^{2}$ moch.zainudiin@unpad.ac.id; ${ }^{3}$ dessy@unpad.ac.id \\ 1,2,3 Pusat Studi CSR, Kewirausahaan Sosial dan Pemberdayaan Masyarakat \\ Universitas Padjadjaran
}

\begin{abstract}
ABSTRAK
Pandemi Coronavirus Disease 2019 (COVID-19) masih menjadi ancaman bagi masyarakat dunia termasuk Indonesia. Peningkatan kasus belum memperlihatkan adanya penurunan angka penyebaran virus. Pemerintah dalam menanggapi krisis kesehatan telah melakukan beberapa kebijakan untuk menekan penyebaran infeksi COVID-19. Adaptasi Kebiasaan Baru (AKB) menjadi salah satu kebijakan baru yang dikeluarkan oleh pemerintah dalam merespon situasi pandemi. AKB bertujuan agar masyarakat dapat melaksanakan protokol kesehatan ketika terpaksa beraktivitas di luar rumah dalam masa pandemi COVID-19. Upaya preventif dan promosi ini harus disebarluaskan kepada setiap masyarakat agar semakin banyak masyarakat menjalankan protokol kesehatan. Kegiatan sosialisasi secara daring melalui media sosial menjadi metode yang ditempuh dalam kegiatan pengabdian kepada masyarakat di masa pandemi COVID-19. Tingginya intensitas penggunaan media sosial menjadi media paling efektif dalam penyebaran edukasi mengenai AKB.
\end{abstract}

Kata kunci: COVID-19, Adaptasi Kebiasaan Baru, Sosialisasi

\section{ABSTRACT}

Pandemic Coronavirus Disease 2019 (COVID-19) is still a threat to the global community, including Indonesia. The increase in cases has not shown a decrease in the spread of the virus. The government in response to the health crisis has implemented several policies to reduce the spread of COVID-19 infection. Adaptasi Kebiasaan Baru (AKB) or adapting to new habits is one of the new policies issued by the government as a response in a pandemic situation. The AKB aims for the public to implement health protocols when they have to do activities outside the home during the COVID-19 pandemic. These preventive and promotional moves should be disseminated to every community so there would be more people who can implement health protocols. Social media is one of the most effective platforms used for this community service program during the COVID-19 pandemic. The high amount of people using social media during this time is the most effective media in disseminating education about $A K B$.

Keywords: COVID-19, Adapting to New Habit, Socialization 
Jurnal Pengabdian dan

Penelitian Kepada Masyarakat (JPPM)

e ISSN: 2775 - 1929

p ISSN: 2775 - 1910
Vol. 2 No.1

\section{PENDAHULUAN}

Coronavirus Disease 2019 (COVID19) merupakan jenis virus baru yang menginfeksi saluran pernapasan manusia. Kasus infeksi virus tersebut pertama kali ditemukan di Cina pada akhir tahun 2019, hingga pada awal tahun 2020, COVID-19 mulai menyebar ke berbagai negara hingga menjangkit hampir di setiap belahan dunia.

Dikarenakan tingkat penyebaran yang cepat, World Health Organization (WHO) sebuah organisasi kesehatan dunia di bawah naungan PBB, pada 11 Maret 2020 telah menyatakan bahwa krisis yang tengah dihadapi ini sebagai pandemi global (WHO, 2020). Begitupun di Indonesia, di mana kasus pertama ditemukan pada awal bulan Maret, penyebaran terus meningkat hingga pemerintah mengeluarkan kondisi krisis kesehatan ini sebagai bencana nasional. Semenjak kasus pertama ditemukan, hingga awal November 2020, COVID-19 telah menginfeksi lebih dari 46,6 juta orang. Di Indonesia sendiri, sejak 7 bulan kasus pertama ditemukan, COVID-19 telah menginfeksi lebih dari 415 ribu orang di seluruh penjuru negeri (Covid19.go.id, 2020).

Langkah-langkah strategik telah dilakukan oleh pemerintah untuk dapat menangani penyebaran virus ini, salah satunya adalah dengan mensosialisasikan protokol Kesehatan pencegahan COVID-19 salah satunya melalui gerakan Social / Physical Distancing. Konsep ini menjelaskan bahwa untuk dapat mengurangi bahkan memutus mata rantai infeksi COVID-19 seseorang harus menjaga jarak aman dengan manusia lainnya minimal 1,5 meter, tidak melakukan kontak langsung dengan orang lain, dan menghindari pertemuan massal (CNN, 2020).

Diberlakukannya social/physical distancing sejauh ini, dipandang cukup efektif dalam menghambat penyebaran virus/penyakit, yakni dengan mencegah orang untuk terinfeksi COVID-19 melakukan kontak dekat dengan orang-orang untuk mencegah penularan. Hal ini dilakukan untuk memutus mata rantai penyebaran virus seperti dengan melakukan pengadaan karantina parsial dan social distancing.

Faktanya, banyak masyarakat yang tidak menyikapi langkah strategik pemerintah tersebut dengan baik. Pemerintah telah membatasi aktivitas masyarakat di seluruh wilayah seperti penutupan tempat publik, kerja sekolah dan pengubahan metode belajar para siswa dan mahasiswa melalui metode daring serta memberlakukan kebijakan untuk bekerja di dalam rumah (Sugiharto, 2020). Namun sangat disayangkan hal tersebut tersebut malah dimanfaatkan oleh banyak masyarakat untuk berlibur (Malik, 2020). Selain itu, walaupun Indonesia sedang dalam keadaan darurat, masih saja banyak orang berkumpul bahkan dalam jumlah ribuan orang di satu tempat, dimana aktivitas tersebut memiliki kerentanan tinggi dalam penyebaran virus corona dalam skala yang jauh lebih besar (Hariyadi, 2020). Selain itu masih banyak juga masyarakat Indonesia yang masih menganggap enteng COVID-19, dengan tidak mengindahkan himbauan-himbauan yang telah dianjurkan oleh pemerintah.

Dalam upaya menekan penyebaran COVID-19, pemerintah menerbitkan PP Nomor 21 Tahun 2020 tentang Pembatasan Sosial Berskala Besar Dalam Rangka Percepatan Penanganan Coronavirus Disease 2019 (COVID-19). Selain itu, pemerintah juga menerbitkan Peraturan Menteri Kesehatan (Permenkes) Nomor 9 Tahun 2020 sebagai pedoman untuk menjalankan PSBB. Dalam Permenkes ini dijelaskan bahwa PSBB dilaksanakan selama masa inkubasi terpanjang (14 hari) dan dapat diperpanjang jika masih terdapat bukti penyebaran. Diberbagai daerah, PSBB diberlakukan baik secara total hingga transisi tergantung pada peningkatan kasus di daerah tersebut.

Dalam penanganan kasus COVID-19, selain pembatasan aktivitas di luar rumah, seluruh ilmuwan dunia berlomba untuk menemukan vaksin yang dapat menyembuhkan infeksi virus tersebut. Namun dikarenakan virus yang menginfeksi ini merupakan jenis baru, menurut WHO penemuan vaksin COVID-19 membutuhkan waktu yang cukup lama (Vanham, 2020).. Hingga kini, perkembangan penemuan vaksin dalam tahap uji klinis. Tingkat penyebaran virus yang terus meningkat dengan pembatasan sosial yang masif membuat terbatasnya aktivitas masyarakat, bisnis, dan pemerintah. Dampak paling besar dirasakan dalam sektor ekonomi. Hal tersebut tercermin 
Jurnal Pengabdian dan

Penelitian Kepada Masyarakat (JPPM) e ISSN: 2775 - 1929

p ISSN: $2775-1910$
Vol. 2 No.1 pada data oleh Badan Pusat Statistik (BPS) bahwa pertumbuhan ekonomi Indonesia pada kuartal II (Q2) mengalami kontraksi sebesar 5,32 persen (Tirto.id, 2020)

Dengan beberapa kondisi tersebutlah pemerintah mengeluarkan rencana new normal yaitu pemberian sejumlah keleluasaan kepada publik untuk dapat beraktivitas kembali di luar rumah dengan melakukan protokol kesehatan. Dengan membuka kembali aktivitas dan aksesibilitas seperti tempat ibadah, hiburan, belanja dan liburan diyakini dapat memulihkan perekonomian baik dalam skala makro dan mikro.

Tujuan dari new normal adalah agar masyarakat tetap produktif dan aman dari COVID-19 di masa pandemi. Dalam sosialisasinya, penggunaan istilah new normal membingungkan masyarakat dan dapat menimbulkan perbedaan persepsi dalam penyelenggaraanya. Sehingga agar new normal mudah untuk diinternalisasi oleh masyarakat, Pemerintah mengubah istilah tersebut dengan narasi Adaptasi Kebiasaan Baru (AKB). Tujuan dari adaptasi kebiasaan baru adalah agar masyarakat dapat bekerja, belajar, dan beraktivitas secara produktif dan aman dari penularan virus di masa pandemi COVID-19.

AKB merupakan perubahan perilaku agar tidak tertular virus Corona melalui pengadaptasian aktivitas masyarakat dengan penerapan protokol Kesehatan sebagai kebiasaan baru (Tumengkol, 2020). Gugus Tugas Percepatan Penanganan COVID-19 memaknai adaptasi kebiasaan baru sebagai perubahan perilaku untuk tetap menjalankan aktivitas normal namun dengan menerapkan protokol kesehatan guna mencegah terjadinya penularan COVID-19. Pemerintah tetap menganjurkan masyarakat tetap di rumah dan hanya keluar jika memang benar-benar diperlukan, terutama bagi orang dengan resiko tinggi terpapar virus seperti orang lanjut usia dan memiliki riwayat penyakit.

AKB merupakan cara perubahan perilaku, gaya hidup dan kebiasaan. Di mana pada tahap ini, Pembatasaan Sosial Berskala Besar (PSBB) di beberapa wilayah di Indonesia mulai dilonggarkan, namun protokol kesehatan tetap dilakukan. Adaptasi kebiasaan baru ini diterapkan pada berbagai sektor atau bidang penting seperti, pasar atau pertokoan, rumah ibadah, perkantoran, transportasi umum, hotel, dan restoran, dan dilakukan saat wilayah sudah menjadi zona hijau yaitu zona aman yang tidak lagi terdampak COVID-19. Adaptasi kebiasaan baru akan berjalan secara efektif jika masyarakat dapat menaati dan konsisten dalam menjalankan protokol kesehatan yang ada.

AKB sebagai upaya menuju masyarakat produktif aman COVID-19 harus mentaati beberapa tips agar tidak terpapar COVID-19 yaitu dengan melakukan:

1. Perubahan perilaku

Perubahan perilaku harus disesuaikan dengan kondisi kebiasaan baru pada masa pandemi COVID-19 yaitu tetap berada di dalam rumah jika tidak berkepentingan. Disiplin dalam melakukan protokol kesehatan saat harus beraktivitas di luar rumah.

2. Hidup lebih bersih

Sesuai dengan anjuran pemerintah melalui Kementerian Kesehatan, hidup lebih bersih menjadi kunci masyarakat aman dari paparan COVID-19. Dengan sering mencuci tangan hingga mencuci pakaian dan mandi setiap beraktivitas di luar rumah.

3. Disiplin protokol kesehatan

Menjalankan protokol kesehatan merupakan kewajiban dalam masa AKB ini. Tetap menjaga jarak, menggunakan masker sesuai standar, melakukan gaya hidup bersih, dan menghindari kerumunan menjadi kunci suksesnya pelaksanaan AKB.

Manusia sebagai makhluk sosial tentu mengalami gagap tradisi dengan adanya pembatasan kegiatan berkumpul dan berinteraksi, bahkan membentuk tatanan baru kehidupan. Ada aspek positif dan negatif dari situasi menantang ini yang turut membentuk dinamika masyarakat agar bisa segera bangkit dari keterpurukan.

Fokus penanganan dalam masa AKB secara preventif dan promotif perlu ditempuh melalui promosi kesehatan melalui sosial media dan media massa termasuk upaya kesehatan berbasis masyarakat di tingkat pemerintah daerah. Upaya tersebut bertujuan agar semakin banyak masyarakat disiplin 
Jurnal Pengabdian dan

Penelitian Kepada Masyarakat (JPPM) e ISSN: 2775 - 1929

p ISSN: $2775-1910$
Vol. 2 No. 1 menjalankan protokol kesehatan dalam masa AKB. Sehingga upaya dalam memerangi virus corona perlu ditempuh, termasuk kegiatan pengedukasian kepada masyarakat agar semakin banyak yang patuh dalam menjalankan protokol kesehatan.

\section{METODE}

Metode dalam kegiatan Pengabdian Pada Masyarakat (PPM) dalam membantu masyarakat untuk melakukan adaptasi kebiasaan baru dalam masa pandemi COVID19 yang dilakukan oleh tim pelaksana yaitu melalui sosialisasi. Sosialisasi menjadi metode yang dipilih untuk membantu masyarakat dalam menghadapi kondisi kritis di masa pandemi COVID-19 ini. Sosialisasi dilaksanakan dengan maksud untuk memberikan informasi dan pemahaman bagi masyarakat dalam menjalankan adaptasi kebiasaan baru dengan menerapkan protokol kesehatan sesuai dengan pedoman yang baik dan benar selama pandemi COVID-19 masih berlangsung.

Sebagai upaya agar kegiatan sosialisasi dapat berjalan dengan optimal, maka diperlukan pendekatan komunikasi yang relevan dengan situasi dan kondisi masyarakat saat ini (Mulyana, 2016). Dalam masa pandemi COVID-19 ini perlu ada penyiasatan strategi penyampaian materi sosialisasi. Hal tersebut disebabkan terbatasnya akses kegiatan di luar rumah dan tingginya risiko melaksanakan kegiatan sosialisasi secara langsung. Maka dalam pelaksanaan kegiatan sosialisasi ini tim pelaksana memanfaatkan media massa sebagai sarana untuk menyampaikan sosialisasi kebiasaan hidup baru dalam upaya meningkatkan kesadaran masyarakat untuk menjalankan protokol kesehatan di masa pandemi COVID-19.

Seiring perkembangan zaman dengan kemajuan teknologi serba digital, menjadikan manusia modern secara umum memiliki gaya hidup yang hampir tidak bisa dilepaskan dari perangkat dan perlengkapan yang serba elektronik (Santoso dkk., 2018: 272). Pemanfaatan media massa berbasis digital yaitu menggunakan media sosial yang terhubung dalam smartphone dipandang sebagai sarana elektronik berbasis daring terbaik yang dapat digunakan dalam penyampaian materi sosialisasi terhadap masyarakat. Hal tersebut dilandasi karena media sosial menyediakan informasi yang cepat dan akurat dengan menyediakan ruang untuk berbagi pesan-pesan positif. Saat ini dengan pesatnya kemajuan teknologi, media sosial menjadi sarana yang paling banyak digunakan di internet. Hal tersebut memudahkan proses penyebaran informasi mengenai adaptasi kebiasaan baru menjadi lebih mudah. Selain itu, pemanfaatan media sosial sebagai sarana sosialisasi dikarenakan banyaknya informasi yang simpang siur mengenai COVID-19. Semenjak kasus pertama COVID-19 di Indonesia, hingga Agustus 2020, Kominfo mencatat terdapat 1016 hoax terkait COVID-19 (iNews, 2020). Sehingga tim pelaksana berusaha memanfaatkan media sosial untuk memberikan informasi yang kredibel, aktual, dan terpercaya mengenai adaptasi kebiasaan baru. Dalam memudahkan diterimanya informasi mengenai adaptasi kebiasaan baru, tim pelaksanaan mengemas materi sosialisasi adaptasi kebiasaan baru dalam bentuk poster infografik yang memuat anjuran mengenai adaptasi kebiasaan baru termasuk pedoman dalam melaksanakan protokol kesehatan dengan bahasa dan ilustrasi yang mudah dipahami.

\section{HASIL DAN PEMBAHASAN}

\section{Sosialisasi Adaptasi Kebiasaan Baru Melalui Media Sosial}

\section{Tahap Persiapan}

Pada tahapan ini dirumuskan rencana sosialisasi adaptasi kebiasaan baru dari perumusan materi, media visualisasi edukasi, penggunaan media sosial sebagai penyebaran informasi, hingga evaluasi kegiatan.

Tahapan ini dimulai dengan perumusan materi edukasi Adaptasi Kebiasaan Baru (AKB) dengan menghimpun materi mengenai AKB dari berbagai sumber. Materi edukasi diakses dari beberapa situs resmi pemerintah seperti situs Satuan Tugas Penanganan COVID-19 melalui covid19.go.id 
Jurnal Pengabdian dan

Penelitian Kepada Masyarakat

(JPPM)

mengenai materi edukasi $\mathrm{AKB}$ selain itu sumber yang digunakan yaitu dari buku Pedoman Pencegahan dan Pengendalian COVID-19 yang dikeluarkan Kemenkes dan Peraturan Gubernur Jawa Barat Nomor 46 Tahun 2020 tentang Pedoman Pembatasan Sosial Berskala Besar Secara Proporsional Sesuai Level Kewaspadaan Daerah Kabupaten/Kota Sebagai Persiapan Pelaksanaan Adaptasi Kebiasaan Baru Untuk Pencegahan Dan Pengendalian Coronavirus Disease 2019 (COVID-19).

\section{Tahap Pelaksanaan}

Pada tahapan setelah materi AKB telah rampung., kegiatan yang dilakukan selanjutnya yaitu pembuatan poster digital sebagai media sosialisasi dari materi edukasi yang telah dihimpun. Visualisasi poster edukasi menggunakan software Photoshop dan Illustrator. Penggunaan media poster bertujuan untuk memudahkan penyampaian edukasi dengan informasi yang singkat, padat, menarik dan mudah dipahami. Pembuatan poster pun mengikuti pedoman ketentuan dalam pembuatan desain agar masyarakat sebagai penerima informasi tidak menimbulkan kebingungan saat membaca atau melihat poster yang akan disebarkan. Poster edukasi AKB harus melalui proses revisi berulang kali untuk memastikan konten dan ilustrasi yang digunakan tepat dan mudah dipahami untuk menghindari anggapan lain yang memungkinkan munculnya misinformasi.

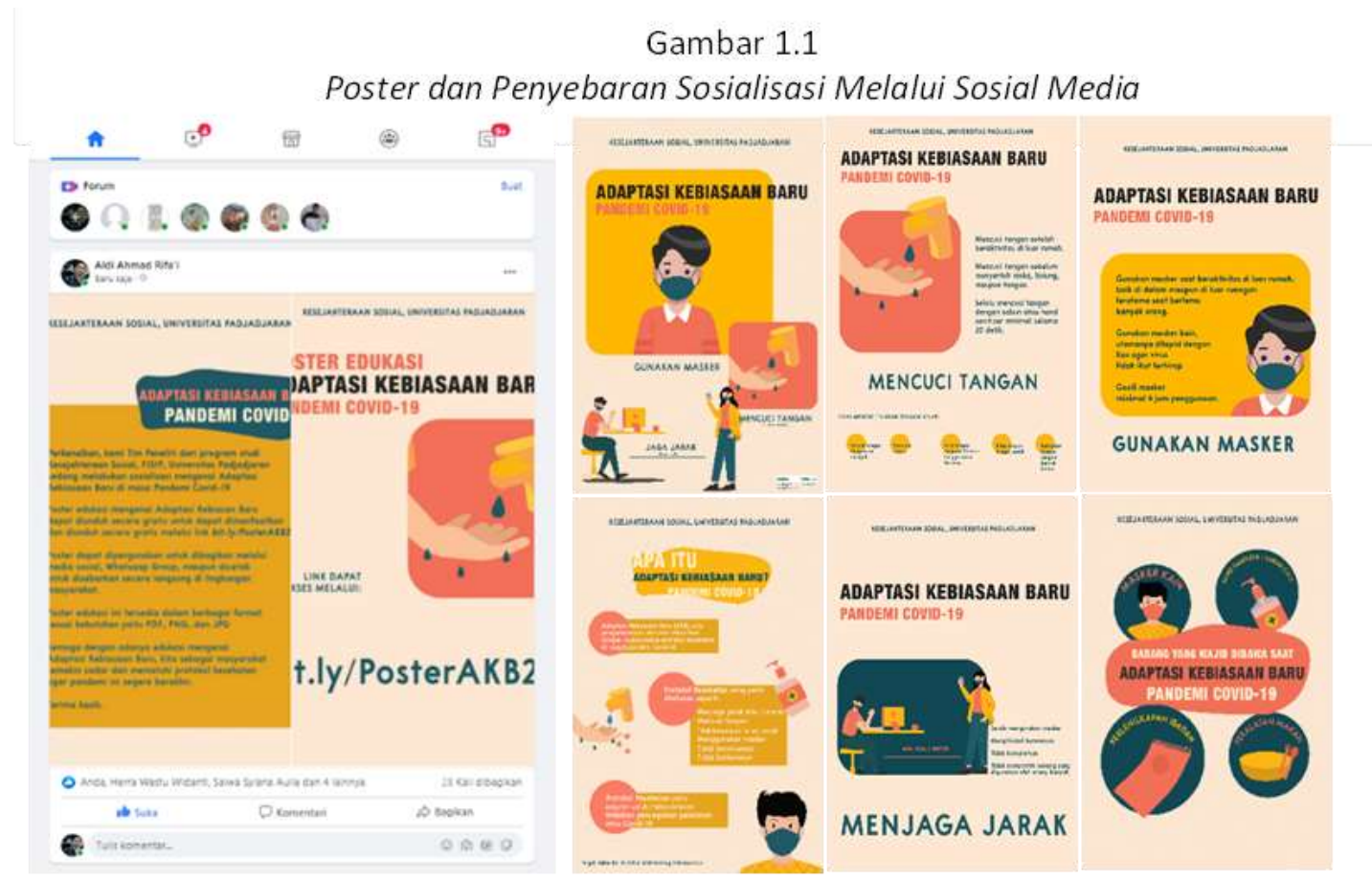

Sumber: Dokumentasi Pribadi Pelaksanaan PPM, 2020

Pelaksanaan kegiatan dilanjutkan dengan melakukan penyebaran informasi poster edukasi AKB melalui media sosial. Media sosial yang tim pelaksana gunakan yaitu Facebook, Twitter, Instagram, dan Whatsapp Group sebagai media sosial yang paling banyak digunakan. Penyebaran dilakukan melalui posting-an mengenai edukasi AKB dengan menyematkan link poster edukasi yang dapat diunduh. Selain itu tim pelaksana memaksimalkan fitur sharing untuk menyebarluaskan informasi kepada keluarga, saudara, kerabat, dan masyarakat luas. Dalam upaya untuk meningkatkan akses penyebaran poster edukasi, tim pelaksana melakukan integrasi dengan penempatan link laman poster pada laman kuesioner daring dari penelitian berjudul "Persepsi Masyarakat Tentang Adaptasi 
Kebiasaan Baru di Tengah Pandemi COVID-19". Penyematan link di kuesioner daring tersebut untuk meningkatkan jumlah kunjungan ke laman poster edukasi AKB, sehingga semakin banyak masyarakat luas yang dapat mengakses poster tersebut.

Penyebaran poster dimulai pada 20 agustus hingga 30 September sesuai dengan masa penyebaran kuesioner daring penelitian yang sedang dilakukan tim pelaksana. Selama masa penyebaran terdapat sebanyak 377 jumlah klik pada link kuesioner daring melalui alamat https://bit.ly/PersepsiAKB20 dengan jumlah akses tertinggi terjadi pada pertengahan bulan September.

Dikarenakan jumlah kunjungan pada laman kuesioner daring tidak menunjukan jumlah kunjungan ke laman poster edukasi AKB pada tautan https://bit.ly/PosterAKB20 sehingga tidak dapat dipastikan bahwa sebanyak 377 masyarakat yang meng-klik laman tersebut melihat atau mengunduh poster edukasi yang telah disediakan. Dengan demikian, tim pelaksana merujuk pada jumlah responden yang mengisi kuesioner penelitian di laman https://bit.ly/PersepsiAKB20.

Terdapat sebanyak 147 responden yang menyelesaikan kuesioner. Hal tersebut menunjukkan bahwa seluruh responden mengakses laman poster edukasi AKB dikarenakan pada akhir pengisian kuesioner, responden dialihkan untuk mengunjungi laman poster edukasi AKB melalui alamat https://bit.ly/PosterAKB20.

\section{Tahap Akhir}

Tahap akhir dalam kegiatan sosialisasi AKB yaitu dilakukan peninjauan hasil survei sebagai bentuk timbal balik masyarakat dari dilaksanakannya kegiatan pengabdian kepada masyarakat dengan diadakannya sosialisasi Adaptasi Kebiasaan Baru secara daring untuk menumbuhkan kesadaran masyarakat di era AKB saat pandemi COVID-19 masih berlangsung.
Hasil survei pada penelitian Persepsi Masyarakat Tentang Adaptasi Kebiasaan Baru di Tengah Pandemi COVID-19 menunjukkan bahwa 97,3 persen responden dari masyarakat yang mengakses laman survey melalui penyebaran link di berbagai media sosial menunjukan bahwa mereka telah mengetahui mengenai AKB.

Media sosial menjadi salah satu media informasi yang paling banyak digunakan responden dalam mengakses edukasi tentang AKB dengan presentasi 68,8 persen. Hal tersebut membuktikan bahwa media sosial menjadi salah satu platform kuat dalam penyebaran informasi di masa kini terutama saat pandemi COVID-19 berlangsung di mana intensitas masyarakat menggunakan media sosial meningkat.

Poin survey lain yang berkaitan dengan kegiatan sosialisasi AKB ini bahwa mayoritas responden sebanyak 143 dari 147 orang percaya COVID-19 ini ada dan berbahaya. Dengan maraknya disinformasi di media sosial, hoax mengenai COVID-19 merupakan agenda konspirasi menjadi ancaman jika masyarakat mudah terpengaruh dengan pemberitaan palsu yang mengakibatkan semakin banyak masyarakat acuh untuk melaksanakan protokol kesehatan. COVID-19 merupakan virus tak terlihat yang siap mengancam kesehatan masyarakat jika abai dalam melakukan protokol kesehatan. Situasi krisis dalam kesehatan ini harus menjadi perhatian banyak masyarakat bahwa wabah virus benar-benar ada dan harus ditangani dengan menghindari setiap aktivitas yang dapat menyebarkan virus di tengah masyarakat.

Poin penting dalam luaran diadakannya kegiatan sosialisasi AKB ini yaitu sebanyak 95.2 responden telah melaksanakan Adaptasi Kebiasaan Baru dalam aktivitasnya sehari-hari. Hal tersebut menjadi respon positif bahwa responden telah sadar untuk melaksanakan protokol kesehatan sebagai upaya untuk menekan penyebaran virus.

\section{SIMPULAN}

Dari hasil kegiatan Pengabdian Pada Masyarakat (PPM) mengenai kegiatan 
Jurnal Pengabdian dan

Penelitian Kepada Masyarakat (JPPM)

sosialisasi kebiasaan hidup baru dalam menumbuhkan kesadaraan masyarakat di era adaptasi kebiasaan baru saat pandemi COVID19, maka didapat kesimpulan sebagai berikut:

1) Sosialisasi kebiasaan hidup baru $A K B$ di masyarakat dalam masa AKB saat pandemi COVID-19 dilaksanakan secara daring dengan memanfaatkan media massa seperti sosial media dan penyebaran kuesioner penelitian dan google drive.

2) Materi sosialisasi disajikan dalam bentuk poster infografik dengan animasi dengan materi yang bersumber dari situs seperti Satuan Tugas Penanganan COVID-19 melalui covid19.go.id mengenai materi edukasi AKB selain itu sumber yang digunakan yaitu dari buku Pedoman Pencegahan dan Pengendalian COVID-19 yang dikeluarkan Kemenkes dan Peraturan Gubernur Jawa Barat Nomor 46 Tahun 2020 tentang Pedoman Pembatasan Sosial Berskala Besar Secara Proporsional Sesuai Level Kewaspadaan Daerah Kabupaten/Kota Sebagai Persiapan Pelaksanaan Adaptasi Kebiasaan Baru Untuk Pencegahan Dan Pengendalian Coronavirus Disease 2019 (COVID19).

3) Terdapat 377 jumlah klik pada link kuesioner penelitian Persepsi Masyarakat mengenai AKB di Jawa Barat dengan total 147 responden yang mengakses laman poster edukasi AKB pada platform Google Form dan Google Drive selama kurun waktu 20 Agustus hingga 30 September 2020.

4) Sebagai hasil tanggapan dari dilaksanakannya sosialisasi AKB, terdapat hasil survey pada penelitian Persepsi Masyarakat Tentang Adaptasi Kebiasaan Baru di Tengah Pandemi COVID-19 menunjukan mayoritas responden telah mengetahui tentang Adaptasi Kebiasaan Baru dan sadar untuk melaksanakan protokol kesehatan dalam era AKB saat masa pandemi COVID-19.

\section{SARAN}

Kegiatan Pengabdian Pada Masyarakat (PPM) dalam bentuk sosialisasi daring tidak dipungkiri mengalami berbagai kendala. Penyajian visualisasi materi edukasi sosialisasi menjadi tantangan untuk mengemas materi agar mudah diterima di masyarakat dan menarik perhatian untuk dapat mengakses poster tersebut. Penggunaan media sosial dalam penyebaran informasi pun harus dievaluasi penyesuaian platform yang paling banyak digunakan berdasarkan umur maupun wilayah. Hal tersebut agar semakin banyak masyarakat yang dapat menerima manfaat dari kegiatan sosialisasi ini.

Pandemi COVID-19 di Indonesia masih berlangsung. Dalam laporan penyebaran kasus, masih belum terdapat tanda-tanda penurunan angka penyebaran COVID-19 di Indonesia. Hal tersebut menjadi tugas penting bagi pemerintah, masyarakat, termasuk tim pelaksana untuk tetap bersama-sama memberikan edukasi mengenai Adaptasi Kebiasaan Baru agar masyarakat tidak abai dalam melaksanakan protokol kesehatan.

Kegiatan Pengabdian Pada Masyarakat (PPM) dalam bentuk sosialisasi daring dapat dikembangkan dengan beberapa rangkaian kegiatan lain seperti melaksanakan webinar kepada masyarakat dengan memprioritaskan masyarakat yang berada di zona merah dengan kasus penyebaran virus corona terbanyak dan mengerucut kepada masyarakat di zona aman. Kegiatan webinar dapat dilaksanakan melalui kerjasama dengan pemerintah daerah untuk membantu memfasilitasi warga dapat mengakses internet dan kegiatan webinar secara daring. Kegiatan ini bertujuan agar terdapat kegiatan interaktif bersama masyarakat untuk saling berdiskusi mengenai pelaksanaan Adaptasi Kebiasaan Baru. Kegiatan webinar menjadi salah satu metode efektif agar sosialisasi tersampaikan secara langsung kepada masyarakat. Tentunya permasalahan teknis dalam hal ini harus diperhatikan, agar penyampaian informasi berjalan dengan lancar, proses diskusi terbuka untuk setiap orang, dan kegiatan sosialisasi dapat diakses oleh masyarakat luas. 
Jurnal Pengabdian dan

Penelitian Kepada Masyarakat (JPPM) e ISSN: 2775 - 1929

p ISSN: $2775-1910$
Vol. 2 No.1

Hal: 80 - 87

\section{DAFTAR PUSTAKA}

ANTARA. (2020). Pedoman Pencegahan dan Pengendalian COVID-19. Retrieved July 21, 2020, from https://www.antaranews.com/berita/15 75051/menaker-protokol-kesehatanadalah-kebutuhan-saat-beraktivitas

Buhler, Charlotte. (1980). Practishe KinderPsychologie. Boston: Hougton. Mifflin,Co. Burn, R.B (1993).

CNN. (2020) Alasan Social Distance Efektif Mencegah Penularan Corona, 2020, diakses dari https://www.cnnindonesia.com/gayahidup/20200316141127-255483855/alasan-social-distance-efektifmencegah-penularan-corona pada 26 Maret 2020

COVID-19 Indonesia. (2020). Apa yang Harus Kamu Ketahui Tentang COVID-19i. Retrieved July 21, 2020, from https://covid19.go.id/edukasi/apayang-harus-kamu-ketahui-tentangCOVID-19/adaptasi-kebiasaan-baru

Hariyadi, D. (2020, Maret 18). Pandemi Corona, Ribuan Orang Ikut Tabligh Akbar se-Asia di Gowa. Tempo.co. Diunduh dari https://nasional.tempo.co/read/132128 5/pandemi-corona-ribuan-orangikuttabligh-akbar-se-asia-di-gowa
Kemkes. (2020). Pedoman Pencegahan dan Pengendalian COVID-19 Juli 2020. Retrieved July 21, 2020, from https://covid19.kemkes.go.id/protokolCOVID-19/kmk-no-hk-01-07-menkes413-2020-ttg-pedoman-pencegahandan-pengendalian-COVID19/\#.XxpgRyj7RnI

Koesmawardhani, N.W. (2020, Maret 17). Pemerintah Tetapkan Masa Darurat Bencana Corona hingga 29 Mei 2020. Detiknews. Diunduh dari https://news.detik.com/berita/d4942327/pemerintahtetapkan-masadarurat-bencana-corona-hingga-29mei-2020

Maulana, R. (2020). Per 5 Agustus, Kominfo Catat Ada 1.016 Hoaks Terkait Covid$19 . \quad$ Diakses melalui https://nasional.okezone.com/read/202 0/09/18/337/2280027/per-5-agustuskominfo-catat-ada-1-016-hoaksterkait-covid-19

Santoso, M. B., Asiah, D. H. S dan Zainuddin, M. (2018). Tantangan Praktik Pekerjaan Sosial Seiring Perubahan Interaksi Sosial Dalam Masyarakat Modern. Prosiding Penelitian \& Pengabdian Kepada Masyarakat. Vol. 5 No. 3 Hlm. 272-280.

Tirto.Id (2020)

Pertumbuhan Ekonomi RI Q2 2020 Minus 5,32\%, Terburuk Sejak 1999. Diakses melalui https://tirto.id/fVQK 